\title{
FROM URBAN FORM TO URBAN RELATIONS: IN SEARCH FOR A NEW KIND OF REFLEXIVE AND CRITICAL KNOWLEDGE IN URBAN GEOGRAPHY AND CITY MONITORING
}

\author{
Jean-Bernard Racine' \\ Institut de Géographie et Ecole des HEC, Université de Lausanne, $\mathrm{CH}-\mathrm{I} 0 \mathrm{I} 5$ Lausanne \\ e-mail: Jean-Bernard.Racine@igul.unil.ch
}

\begin{abstract}
The paper explores what unites the social environment the material environment. both the material form, and, jointly, the sensibility that echoes it. .It argues that urban geographers need to develop a research model drawing on urban geography, on urbanism and on land management and capable of integrating the thoughts, the emotions, the affects and the values of city dwellers and citizens and therefore knowledge situated at a micro-social level. However, such research still would need to lead to truly regulatory knowledge. Its translation into practical measures needs to be democratically approved, especially by actors who know how to think and act both locally and globally, in relation to multiple and complex territories of affiliation and intervention. This implies a huge effort of the imagination and of construction, both at the theoretical level and at the level of the operational tools needed. Indeed, the concept of " urban project", which has been frequently encountered since the end of the " $70 \mathrm{~s}$ and which is supposed finally to supersede functionalist urbanism, cannot be conceived of without taking into consideration the population's capability to participate and embrace projects or, on the contrary, to oppose them.
\end{abstract}

Key words: Innovative scientific knowledge, social science, urban form, sustainability, relation, lifeworld, socio-affectives relations and analysis, urban research agenda

\section{OUR KNOWLEDGE AT STAKE}

The issue needs to be addressed: through the multiplication of our "assignments" and research papers, don't we risk contributing to the transformation of inevitably arbitrary political choices into more or less objective technical choices, " by way of managing the

\footnotetext{
${ }^{1}$ A more developped version of this paper, in french, have been published in P. Bridel, éd. L'invention dans les sciences humaines, Genève, Labor et Fides, 2004, pp. 98-125
} 
inertias and the mirages of societies less and less capable of shaping their future and of defining ideals and hope ? Do we still truly produce a theoretical knowledge ? Can such knowledge be produced today, knowing that society exhorts us to be empiricists and datagatherers and that those who sponsor research projects favor practical, " usable and profitable " projects? What kind of questions do we need to ask in order to bring to light the emerging knowledge demanded by F. J. Varela (1996) ? Such questions need to be asked by our disciplines and by geography in particular - urban geography to be more pre-cise.

I have asked myself the questions as a geographer having sacrificed much to the study of cities in a variety of geographical contexts and along a multitude of conceptual and methodological lines of approach, the qualitative approach and the socio-cultural reference, phenomenological and hermeneutical preoccupations having progressively replaced ambitions of a more positivist nature, being empirical and formal, quantitative and favoring modeling, drawing initially on functionalism and applied at first to the socio-economic domain (Racine, 1975, 1993, 2002, 2004). To illustrate this discussion, I will take as an example the issue of the urban form, much as many other examples could be used. My choice might seem unexpected. I shall say simply that this topic is "basic" both because of its place in any urban study and in light of its comeback in the specialized literature. However, it must be said that the topic of the urban form and of formal specifities of space has been massively discussed in the scientific literature in more or less original ways.

\section{THE RETURN OF THE FORM: A TERRAIN FOR BOTH ANCIENT AND CURRENT QUESTIONS}

In the more general context of the question of the social rapport to materiality, the old question of the urban form is considered again today in a new context, one defined by the perspective adopted by sustainable development. Thus, the study of the urban form is currently considered as one of the major dimensions contituting the analysis of "regime of urbanization", besides the analysis of spatial relationships between cities and agglonerations and their different spatial envirlopes and besides its effects in termes of use of ressources and in termes of pollution at the environmental level and in relation to its effects on the quality of life of city dwellers.

For example, nothing prevents us from asking ourselves what the relationships between urban forms, or " regimes of urbanization", and the health of the population living in them could be. A recent amazing article by Daniel Z. Sui (2003), appeared in Urban Geography, has given serious thought to the possible relationships between urban forms and public health, by linking the anthropomorphic but imaginative metaphor of the " fat city ", describing sprawling cities, to the obesity that plagues more and more Americans.

The specification of the nature of such interactions will doubtless prove to be very helpful in understanding the way of living the emerging city! It is also an issue of form, but placed in a different perspective: it is just as legitimate to delve into the historical components of the present territory and to try to distinguish what belongs to ancient, modern or recent 
strata (Malfroy, 2000). Some simply reproduce, in a generalized intertextuality, views that have long being agreed upon, on the analysis of the urban landscape and of the visual aspects of the environment, as well as its value in terms of amenities (Whitehand, 1981, 1992). Other, more original, ones, like the ones of the Schools of Architecture of Paris-Villemin and of Versailles (Panerai, Castex, Depaule, 2001), by following the avenues opened by S. Muratori (1960) renew the morphological analysis by trying to " recreate the discipline" with very precise ambitions in mind. Some English researchers, sometimes the same ones (Whitehand, 1987, 2001), have proposed a deductive theory of fringe belts which tries to relate the dynamic and the processes of physical renewal to the cyclic variations of the cost of land, in a way that may seem more interesting to those who criticize the excessively empirical and descriptive nature of studies in urban morphology. We may agree with E. Ducom (2003) in thinking that studies in the variation of the nature of urban edges according to the period of time and to the distance from the center and according to the decisions of individuals and of organisms attentive to economic cycles and to the cost of land may have a prospective or even predictive value. However, this anticipation doesn't tell us anything more about the quality of the population's relation to space ensuing from this form of growth.

\section{FORM AND SUSTAINIBILITY}

It can doubtless be shown, as stated by A. Cunha and B. Bochet (2002) in their ten theses on urban sustainable development and on the control of the social dynamic, " that a city characterized by short distances needs fewer resources" and that " the combined organization of collective transportations and of spatial allocations improves the economic, social and environmental situation". Nevertheless, the authors acknowledge that more than ten years of research have yet to provide any conclusive evidence capable of highlighting the direct and indirect costs of concentration and of dispersion at the triple economic, social and ecological level. The advocates and the adversaries of the compact city and of the expanded city thus seem to be overwhelmed by these compromisers, advocates of a " new urbanism" and of the polynuclear or polycentric model (Breheny, 1996, Camagni and Gibelli, 1997). B. Bochet and G. Pini (2002) draw a very legitimate conclusion, holding that " the major task isn't to conceive of an ideal urban form, rather to " reconceive of" the extant forms and to take into consideration the need for different lines of approach at the planning and at the conceptual level so that these forms can become sustainable ". We may also quote S. Guy and S. Marvin (2000) who recommend " trying to identify the complex paths through which different urban forms may claim sustainability", rather than looking for a static model of a sustainable urban form. May we bear this in mind.

The plea in favor of densifying cities, seeking to curb the habitat's dispersal in favor of models drawing resolutely on a specialized multicentrality, is currently quite common, much as some of the statements condemning the dispersed city are already contested. Two critics are P. Gordon and H.W. Richardson (1997), who ask whether compact cities are a 
desirable objective of land management and who question the efficiency of compactness, minimizing the economic gains and the environmental benefits that would result from its implementation.

However, it must be pointed out that even when it comes to " formal " and apparently well-defined relations, such as the one stating that density is inversely proportional to the consumption of fuel (Newman and Kenworthy, 1999), a relation of cause and effect cannot be automatically derived. Not only are the empirical data oftentimes not very reliable and hardly comparable from one context to another but, like everybody knows, not all variations are the expression of a relation of cause and effect. And even when such a relation exists, what is then the cause and what is the effect? Are low densities the cause of traffic or is motorization that allows people to live farther away from the center, having more space at their disposal, i.e. low density? P. Merlin (2000), reminds us that we do know "that causality is a two-way relation, and the two elements strenghten each other and reach a balance that has been instable up to this day".

The progress made in quantitative analysis, combined with advances in geomatics, seem to have given new life to the study of distributions and of morphologies and, particularly at the present time, of the spatial growth of cities and of their fragmentation, as well as of their relation to mobility, to an intermingling deemed necessary and to anything that seems to condition a type of development supposed to be conceived of according to explicit choices resulting from a multicriteria and sustainable approach and grounded in the knowledge necessary to make a decision. Especially in the context of the urban form, these tools doubtless contribute to a sizable increase in our knowledge and open it up to some of its correlatives, at all levels, and particularly well at the intra-urban level. Multidimensional and multicriteria spatial data processing accounts for this particularly well.

However, we still need to ask ourselves to what extent it may be possible to produce knowledge that gives meaning and value to information and that helps understand, beyond the spate of details provided by Geographic Information Systems, for example, the import of changes in the urban form for those who dwell in it. As stated by P. Villeneuve (2002), it can well be shown that greater mobility "increases the "plasticity" of women in the performance of their activities". Yet what conclusions can we draw ? A greater social equity between genders? Or rather does this new plasticity "justify an unequal, gender-based division of labor" ? At a more general level, we should keep asking ourselves whether our quantitative analyses, although so useful to us, really help us fathom the social substance characterizing the spaces where everyday life activities are carried out (Thérault et al. 1999).

\section{A SIMPLE QUESTION OF FORM? A CONCEPTUAL LEGACY THAT NEED TO BE ACCEPTED AND MOVED AHEAD OF}

Evidently, beneath the different representations of an ideal compact form, lie the old models found in student manuals that have trained a majority of geographers (Senecal and Hamel, 2001). The classical theory of urban space is built on the premise that " a city lives 
through its center", "ground for activities and for the accomplishment of responsibilities and satisfactions of a higher order; prestige, information and interconnections are its apparently irrefutable attributes; a metropolis controls, presents, distributes and gathers by virtue of its center" (Labasse, 1966).

The current representations of the meaning and future of urban form doubtless owe their nature to the persistence, in the mind of geographers, of the North-American founding models of sociology and of urban geography, conceived by the School of Chicago. Twothirds of a century after these pioneering works, we have inherited from such models a series of fundamental representations of what lies beneath the urban form. First of all, the fact that density gradients follow land-cost gradients and sustain ecological urban structures. Second, the fact that high values of land in the center of cities are revealed by the extreme compactness of buildings and by the good accessibility of central spaces. In this context, the residential breakdown evolves also according to gradients between center and periphery, from apartment buildings to low-density suburbia. Third, the fact that this structuration depends also on the images of the city, in terms of values, of meaning, of signification and on the very forms constituting the urban landscape, among which the presence of nature plays a central role. This third aspect was largely developed by K. Lynch after W. Firey (1945) brought it up in relation to Boston in his critique of the classic models of the School of Chicago.

Such were the standards of theory in urban geography. These standards have been debated since their inception. More so since the emergence of what some have called the third movement of periurbanization and others of counter-urbanization, while activities specific to centrality were being decentralized, following residential and commercial functions. The appearance of centers of secondary order, edge cities (Garreau, 1988), or other major suburbs became the designation of a recasting of the classic model. The polycentric form claims to be an alternative to hypercentrality and to urban spreading in that it could reduce the number of cummuters and therefore curtail pollution as well as land pressure on the natural environment (Ewig, 1997).

Hence, new words and new concepts are being invented to describe the American New City (Fishman, 1990), and the sometimes contradictory implications of metropolization, which has superseded urbanization. A fragile balance characterizes it and it behooves us to start to analyze its tendencies, which may only appear to be contradictory, contributing either to the decline of centers or to the attribution of greater value to centrality. Which means it is still worthy to delve into it, like M. Bassand (1997) does, trying for example to understand what, in a city, gathers or informs, what, especially, acts as a system of reference for the action of city-dwellers.

We shall retain, however, the deliberate and optimistic perspective that emanates from the analyses carried out by V. Kaufmann (2001) and his collaborators on European cities. The conclusion they draw is that this much-decried periurbanization is not fatal and that by being sufficiently imaginative, other modes of urbanization are possible, especially in the suburbs close to the center, " provided that these spaces can be given more value at the actual and at the symbolic levels". A notation that seems essential to me, especially because it is anchored in a key question. How can we possibly think the urban dynamic from a 
perspective defined by sustainable development, by analyzing the constraints and the opportunities linked to the urban form but by omitting the analysis of the aspirations, the satisfactions and the arbitrations linked to their more or less high level of convergence and to the rules of the game? (Kaufmann, Jemelin, Guidez, 2001). And, above all, as V. Kaufmann would say, by lacking imagination and by not offering any other model than the classic dichotomous image of the city-center (no opportunities to develop)/diffuse periur-ban city encouraging the generalized use of the automobile. Can we do any better?

\section{A CITY TO INVENT OR A CITY THAT INVENTS ITSELF? THE RELATION TO THE CITY AS A SOCIO-AFFECTIVE RELATION}

In this connection the issue addressed by Y. Chalas (2000) is particularly interesting. He first reminds us that "the city is neither ahistorical nor transhistorical, and that it changes not only in its form, or what can be called its landscapes, its aesthetic appeal, but also in its fundamental structure, its organization, the hierarchy of its different centers or of its different facets, the lifestyles of its inhabitants, etc. ". In other terms, the city " is not the result of an identical reproductive process". Being historical, it is an invention and a permanent reinvention, "a social and historical creation" as C. Castoriadis would say (1975), "meaning that it is what people make of it and not only what people inherit". The city, which always appears to be different from itself and from other cities, is the result of a transformation that man hasn't - at least in part - wanted or mastered. It is in this context that Y. Chalas places the task of urban research. Thus, he joins us in our interests, which " consist in constantly deciphering the city's evolution, and therefore producing new models to understand the city so as to rethink these renewed entities and propose these models to those who act on the city to modify or strengthen its tendencies - if research has to be at least partly useful". This means specifying the process that leads to the invention of the city, along three lines of approach he deemed appropriate: the social imagination, dwelling practices, the architectural and urbanistic epistemology.

What should we retain? Mainly the fact that in addition to the rapport between what he qualifies of " primordial in the city" and what will give each one its peculiarity, "if not within a same society or a same culture, at least from one society or culture to another", there is what proceeds from invention. The primordial element evidently refers to the very genesis of the urban phenomenon, to the extraordinary anthropological phenomenon represented by the appearance and the disappearance of the city throughout history. Almost invariable, these structural elements belong to what all cities have in common. C. Raffestin (1977) identifies them to the "very principles of the idea of city", centration, concentration, heterogeneity, power and regulation. Y. Chalas (2001), identifies them with a series of founding antagonisms, both external and internal (between city and nomadism and between city and country), " a multiplicity of oppositions within themselves, in the form of a functional division from which only can it be stated that there is a city". These contradictions can also be a source of concord and of creation, by forming a complex system that gives it its multiple meanings. The invention refers to a few specific, "identity-related and meaning- 
ful " traits, that coexist with it and that confer on it, in new ways, singularity and historic adaptation, some elements being potentiated, others being rearranged differently. "The only thing that changes through history, is the organization of these elements " (ibid).

These quotations and this epitome of Y. Chalas' thinking help us situate our problem. Have we exploited the leeway given us by our evolving cities, by inventing instead of letting them invent themselves? The processes haven't been understood, and we have limited ourselves to finding purely managerial and technical solutions, with no other ambition in mind. There has been a lack of sufficient theoretical knowledge and of a holistic, prospective outlook, capable of defining a desirable future which has resulted in a lack of sufficiently solid critical thinking. This has resulted in purely pragmatic, unscientific policies, characterized by a lack of knowledge and of imagination, our eyes being fixed on the status quo. It thus seems that we have made many mistakes. Is there an alternative to acting belatedly on negative impacts nobody wants to be responsible for?

\section{ON FROMS AGAIN: THE URBAN FORM AS RELATION}

"An urbanist, after all, should be first an inhabitant", wrote D. Mangin and Ph. Panerai (1999), two specialists of urban analysis. They consider " the urban form as implication" and are interested in ways we can build cities taking into consideration not only the preoccupations of technicians but also the economic, cultural and social aspects. These authors hypothesize that " rigorously relating the allocation of land to the type of buildings, provides the initial framework for an urban tissue likely to favor appropriations and adaptations", by offering city-dwellers a framework likely to adapt to changes in their lifestyles and in the economy. However, the foregoing quotation encourages us to move beyond what they themselves say, so as to conceive of the city not through buildings but through urban forms in an "urban project" working as a tool of mediation between buildings and their city .

Specialists oftentimes criticize, legitimately, "the limits of an action concerned merely with buildings and not with the relations between them " (ibid). It is necessary to know what they mean by the notion of relation in this connection. These texts will disappoint readers, users, inhabitants and specialists and politicians concerned with " making city". Even though these will admire the analysis of the complex relations between land and buildings, between roads and buildings, between forms and practices, they still will say that the last term, indissociable, but otherwise more complex still, is being sacrificed. Does the outlook on the city, on the relation between life and the city, have to come from a sociologist who would also be a novelist and a musician (Sennett, 1992), or from a writer (Gracq, 1985), to be capable to link forms to the way we look at them, to link the morphological element, in its spatial and temporal complexities, to the socio-cultural or socio-affective element? (Bochet and Racine, 2002).

This is precisely what has been illustrated with enthusiasm by the geographers W.K.D. Davies, J. Chan, and I.J. Townshend (1999), Townshend and Davies, (1999) and again Townshend (2002) in their remarkable works on the chinese and on the elder communities of Calgary and of Lethbridge, Alberta. In their studies, they associated to their 
factorial ecologies objective and subjective measures and discovered quantitatively the high degree of empirical correspondence between concepts associated to behavioral, cognitive and affective dimensions of the variation identified within these communities. These works considerably renew the classic studies of urban areas and show that these concepts can be studied in a complete urban context, rather than being limited to previously defined social niches. They also show that those conceptual models of differentiation of communities which take into consideration the affective, cognitive and emotional dimensions of populations are quite reliable even when the whole of the social areas of the city are included in the analysis, social areas which, when taken individually, don't generate any significant differences.

Which is also why we argue in favor of abandoning a purely formal and functionalist perspective, that distances experiences as they are lived and which defined the positivist, scientific objectivity of modernity. Our efforts should thus seek to pursue the more ambitious project of mastering the connections between the world as such and the world as we experience it. Such a perspective doesn't necessarily set the social environment against the material environment. Rather, it explores what unites them, both the material form, and , jointly, the sensibility that echoes it (Berque, 1990). In other words, we need to develop a research model drawing on urban geography, on urbanism and on land management and capable of integrating the thoughts, the emotions, the affects and the values of city dwellers and citizens and therefore knowledge situated at a micro-social level. However, such research still would need to lead to truly regulatory knowledge. Its translation into practical measures needs to be democratically approved, especially by actors who know how to think and act both locally and globally, in relation to multiple and complex territories of affiliation and intervention. This implies the development of technically and spatially adequate systems. The constraints of each place also need to be taken into consideration. This also implies a huge effort of the imagination and of construction, both at the theoretical level and at the level of the operational tools needed. Indeed, the concept of " urban project", which has been frequently encountered since the end of the " 70 s and which is supposed finally to supersede functionalist urbanism, cannot be conceived of without taking into consideration the population's capability to participate and embrace projects or, on the contrary, to oppose them (Toussiant \& Zimmerman, 1998).

It is also necessary to discover or at least to give a new interpretation to what sustains and nourishes the socio-affective relation to the city as well as the meaning which can be attributed to it. The question being whether in the context of this relation, the city is an actor in and of itself or rather through one of the dimensions that cause it to exist for this other actor - an acting agent - which is the individual dwelling in it and lives it in a given system of social and spatial relations: dimensions of urbanity, of amenities, of civilities (Bochet and Racine, 2002) and of everybody's capability to love the people of their city. Or should we instead look into the personal element, into the set of one's social relations? And if, as we may hypothesize, the answer lies between two issues of " the actor as acted upon ", as N. Elias (1985) would say, in the dialectic nature between city and city-dwellers, what lessons can we draw in terms of public policy and of good governance? 
First, we need to know who is concerned by this set of relations and for what reasons, at the double level of effects and of a desire to organize space: it is the question of the fundamental knowledge of a relation system implying simultaneously materiality and immateriality. Second, we need to know whether the actor should be considered as an individual isolated in his habitus or as an element of a collective habitus. The question is being asked as the urban form evolves towards a metropolitan form. This evolution implies not only spreading and fragmentation, generally brought up by every author, but also individuation. Third, as fulfiller of roles or as organizer of the elements of his system of action, having found in the city spaces of gratification (Laborit, 1974 ; 1994), of mimetic mediations (Girard, 1961), the possibility to enliven his imagination (Noschis, 1984), likely to nourish and satisfy his socio-affective relation.

This is the very crux of the problem facing city dwellers: the fact that between subject and object, between nature and culture, the essential takes places in the double movement between the two - mediatory leifmotiv that has been rigorously illustrated by the science des milieux elaborated by A. Berque (1990). In other words, a landscape is not a thing, but a relation. The same goes for any urban form. Material forms are social forms, as has been said repeatedly since H. Lefebvre (1974) and M. Castels (1977). They have a history, " they are their own histories ". Don't they, at the intersection of geography and history, serve as " mediation between the world of things and the one of human subjectivity", like the landscapes of A. Berque (1995), "place-forms" (Frampton 1993), but also " ecosymbols" through which our future is written and elaborated ? It is therefore necessary to study " the cognitive cogency of space", and the way space in its contents, its organization and its representations directs and informs the psyche looking at it. In addition, it is necessary to underscore the affects and emotions of individuals in relation to their city, but also the way the city enters the individual experience and takes on its own affects. Such is " the city that gives itself as something effecting something in its inhabitant, that causes something to be defined to resonate in him, an affective phenomenon, which is an effect of the world on his sensibility, the power of his thought to recognize himself in this city, to be strenghtened through an affective and emotional rapport to space and this, probably, independently of any symbolic content" (Wunenburger, 1997). As J .P. Sartre remains us in L'Etre et le Néant: " the form doesn't exist as pure exteriority". In other words, "it is the relation that makes the world" and it is through human reality that there is a world.

\section{TOWARD THE EXPLORATION OF AN EVIDENT INEXPLO- RED RELATION: AN AGENDA FOR URBAN RESEARCH?}

Let's leave the word of conclusion to my friend A. Berque, who commented my first draft in these terms: " in fact you plead for a deliberate insertion of the urban forms question in the pluridimensional problematic of social sciences, referring in particular to H. Lefebvre's work. In short, to consider them as social forms. I absolutely agree with you (...). I say that urban forms are social because they are our social body, I would say in my language, our "medial body". In other terms, an aspect of our milieu, that milieu which is the "half" of 
our existential structure. In this way, they partake of our very identity. That thesis being that in architecture, urbanism and urban planning, it is on relation that we must act and not only on forms, which are just one part of the two components of our social body, of our existential structure. A policy which would be only formal (as Le Corbusier proposed it) or a policy only social (as critical sociology suggests), would be unable to solve the question of urban form. That means that there is no ideal urban form (as you said). The city should not be compact or diffuse, monocentric or polycentric - that depends on its history and on its milieu. A pure ecological sustainability means nothing: we should fight for a true ecumenial relevance, both and simultaneously in terms of history and environment. That means that we should invent the city (as Chalas would say) at each moment, in each place, considering each history, each milieu. That has nothing to do with the simple transfer of forms or of foreign recipes, nothing to do with the post-modern pastiche of ancient local forms, which are the two dominant ways of doing in the actual world. We should create, always create and yet be mindful of history and milieu. This means being respecful of others and being open to deep and thought-provoking questions about being and cosmicity».

\section{References}

Bassand, M. (1997) Métropolisation et inégalités sociales, Lausanne, Presses polytechniques et universitaires romandes.

Berque, A. (1990) Médiance. De milieux en paysages, Montpellier, GIP RECLUS, 163 p.

Bochet, B. et Cunha, A. (2002) Développement urbain durable, Vues sur la ville, 1, pp. 1-5.

Bochet, B. et Pini, G. (2002) Formes urbaines et mobilité: quelles stratégies pour un développement durable? Vues sur la ville, 4, pp . 3-5.

Bochet, B. et Racine, J.-B. (2002) Connaître et penser la ville: plaidoyer pour l'exploration des affects et des émotions dans la géographie urbaine, GéoCarrefour, 77(4).pp. 117-132

Bordas, F. (1999) Densité perçue et forme architecturale, Villes en parallèle, no.28-29, pp. 141-161

Busino, G. (2002) Fragments d'un livre d'histoire de la sociologie. La sociologie à bout de souffle, à la dérive ou en déroute, Revue européenne des sciences sociales, XL(122), pp. $67-118$.

Camagni, R. et Gibelli, M. (1997) Développement urbain durable: quatre métropoles européennes à l'heure de l'épreuve, Paris, Datar, Ed. de l'Aube.

Camagni, R. Gibelli, M.C. et Rigamonti, P. (2002) Forme urbaine et mobilité: les coûts collectifs des différents types d'extension urbaine dans l'agglomération milanaise, Revue d'Economie Régionale et Urbaine, no. 1, pp.105-140

Castells, M. (1977) La question urbaine, Paris, Maspero.

Castoriadis, C. (1975) L'institution imaginaire de la société, Paris, Seuil.

Chalas, Y. (2000) L'invention de la ville, Paris, Anthropos - Economica, 199 p.

Clément, C. et Nathan, T. (2002) Le Divan et le Grigri, Paris, Odile Jacob.

Davies, W.K.D., J. Chan, and I.J. Townshend (1999) How Do Communities Differ ? Empirical Evidence for Behavioral and Cognitive-Affective Dimensions of Community, in Problems of Megacities: Social Inequalities, Environmental Risk and Urban Gover- 
nance, edited by A.Aguilar and I. Escamilla, Universidad Nacional Autonoma de Mexico, Institute of Geography, pp. 529-542

Desmarais, G. (1995) La morphogenèse de Paris. Des origines à la Révolution, Paris, L'Harmattan.

Ducom, E. (2003) La théorie des ceintures limitrophes (fringe belts): discontinuités d'occupation de l'espace sur les franges des villes, L'Information géographique, vol 67, no. 1, pp.35-44

Ewing, R. (1997) Is Los Angeles-Style Sprawl Desirable ? Journal of the American Planningf Association, 61(1), pp. 107-126.

Firey, W. (1945) Sentiment and Symbolism as Ecological Variables, American Sociological Review, 10, pp. 140-148.

Frampton., K. 81993) Towards a Critical Regionalism: Six points for an architecture of resistance, in Docherty, Th. (ed.) Postmodernism: a reader., New York, London, Harvester-Wheatsheaf

Garreau, J. (1988) Edges cities, Lanscape Architecture, 78(8), pp. 48-55.

Gordon, P. et Richardson, H. W. (1997) Are Compact Cities a Desirable Planning Goal? Journal of the American Planning Association, 61(1).

Elias, N. (1985) Norbert Elias par lui-même, Paris, Agora.

Gracq, J. (1985) La forme d'une ville, Paris, José Corti.

Girard, R. (1961) Mensonge romantique et vérité romanesque, Paris, Grasset.

Guy, S. et Marvin, S. (2000) Models and Pathways. The Diversity of Sustainable Urban Futures, in: Williams et al (éds.) The Compact City, Oxford, Spon, pp. 9-18.

Isin, E. F. (1996) Metropolis Unbound: Legislators and Interpreters of Urban Form, in: Caulfield. J. et Peake, L. (éds.) City Lives \& City Forms. Critical Research and Canadian Urbanism, Toronto, University of Toronto Press, pp. 98-127.

Labasse, J. (1966) L’organisation de l'espace: éléments de géographie volontaire, Paris, Hermann.

Laborit, H. (1994) L'agressivité détournée. Introduction à une biologie du comportement social, Paris, Union générale d'éditions.

Malfroy, S. (2000) Penser et représenter la ville, Lausanne, ENAC, EPFL, 369 p.

Mangin, D. et Panerai, P. (1999) Projet urbain, Marseille, Parenthèses, 185 p.

Merlin, P. (2000) Préface, in: Fouchier, V. Les densités de la Ville nouvelle d'Evry. Du projet au concret, Paris, Anthropos.

Muratori, S. (1960) Studi per una operante storia urbana di Venezia, Rome, Instituto Poligrafico della State.

Panerai, P., Castex, J. et Depaule, J.-P. (2001) Formes urbaines de l'îlot à la barre, Marseille, Parenthèses, $197 \mathrm{p}$.

Noschis, K. (1984) Signification affective du quartier, Paris, Méridiens, 170 p.

Racine, J.-B. (1975) Un type nord-américain d'expansion métropolitaine: La couronne urbaine du Grand Montréal (Géographie factorielle expérimentale d'un phénomène suburbain), Lille, Service d'Editions des thèses,

Racine, J. B. (1993) La ville entre Dieu et les hommes, Paris, Anthropos, Genève, Presses bibliques universitaires 
Racine, J.-B. (2002) Migration, Places and Intercultural Relations in Cities, in: Schnell, I. and Ostendorf, W. (éds.) Studies in Segregation and Desegragation, Aldershot, Ashgate Publishing Ltd, pp. 67-86.

Racine, J.B. (2004) Forme urbaine, relation à la ville et invention disciplinaire: savoirs et savoir-faire géographiques en question, in Pascal Bridel, ed. L'Invention dans les sciences humaines, Hommage à Giovanni Busino, Genève, Labor et Fides, pp.98-125

Raffestin, C. (1977) La ville comme métaphore, Médecine et Hygiène, 1, pp. 37-50.

Raffestin, C. (1977) La ville comme métaphore, Médecine et Hygiène, 1, pp. 37-50.

Sartre, J.-P. (1943) L'Etre et le Néant, Paris, Gallimard, 724 p.

Sénécal, G. (1996) Champs urbains et développement durable: les approches canadiennes de la ville écologique, in: Natures, Sciences, Sociétés, Paris, Dunod, 4.

Sénécal, G. et Hamel, P. J. (2001) Ville compacte et qualité de vie: discussions autour de l'approche candienne des indicateurs de durabilité, Le Géographe canadien, $45, \mathrm{n}^{\circ} 2$, pp. 306-318.

Sui, Z. D. (2003) Musings on the fat city: are obesity and urban forms linked ? Urban Geography, 24, 1, pp. 75-84

Thériault, M. et al. (1999) A Spatio-Temporal Data Model for Analysing Personnal Biographies, in: Tjoa, A.-M. et al. (éds.) Tenth International Workshops on Database and Expert Systems Applications, IEEE Computer Society, Los Alamitos, California, pp. 410-418.

Townshend, I.J. et Davies, W.K.D. (1999) Identifying the Elements of Community Character: A case study of Community Dimensionality in Old Age Residential Areas, Research in Community Sociology, 9, pp.219-251

Townshend, I.J. (2002) Monitoring Community Dimensions: City-Wide Characteristics and Differentiation by Social Area Type, in Monitoring Cities: international Perspectives, édited by W.K.D. Davies and I.J. Townshend, IGU, Urban Commission, Department of Geography, University of Calgary and Free University of Berlin, pp.435-459

Toussaint, J.-Y. et Zimmermann, M. (1998) Projet urbain. Ménager les gens, aménager la ville, Paris, Mardaga.

Varela, F. J. (1996) Initiation aux sciences cognitives, Paris, Seuil.

Villeneuve P. (2002) Territorialité, interaction spatiale et rapports hommes-femmes, Cahiers Géographiques. La territorialité: une théorie à construire. En hommage à Claude Raffestin, 4, pp. 103-109.

Whitehand, J. W. R. (éd.) (1981) The Urban Lanscape: Historical Development and Management, Londres, Academic Press.

Whitehand, J. W. R. (1987) The Changing face of cities. A study of development cycles and urban form, Oxford, IBG Special Publication, Basil Blackwell

Whitehand, J. W. R. (1992) The Making of the Urban Landscape, Oxford, Blackwell.

Whitehand, J. W. R. (2001) The physical form of cities ; a historico-geographical approach, in D. Paddison (éd.) Handbook of urban studies, Londres, Sage publications

Whitehand, J. W. R. (2001) Changing suburban landscape at the microscale, Tijdschrift voor Economische en Sociale Geografie, vol.92, pp.164-184 